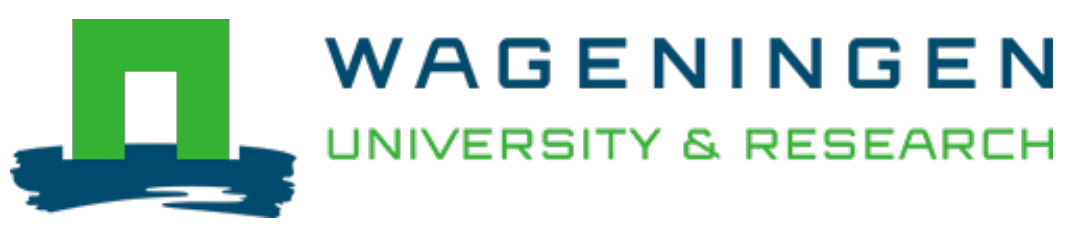

\title{
Bee mietii rak rkabni nis (The people know how to seed water) : A Zapotec experience in adapting to water scarcity and drought
}

\section{Climate and Development}

Basel, Britt; Hernández Quiroz, Nadir; Velasco Herrera, Roberto; Santiago Alonso, Carmen; Hoogesteger, Jaime

https://doi.org/10.1080/17565529.2020.1855100

This article is made publicly available in the institutional repository of Wageningen University and Research, under the terms of article $25 \mathrm{fa}$ of the Dutch Copyright Act, also known as the Amendment Taverne. This has been done with explicit consent by the author.

Article 25 fa states that the author of a short scientific work funded either wholly or partially by Dutch public funds is entitled to make that work publicly available for no consideration following a reasonable period of time after the work was first published, provided that clear reference is made to the source of the first publication of the work.

This publication is distributed under The Association of Universities in the Netherlands (VSNU) 'Article $25 \mathrm{fa}$ implementation' project. In this project research outputs of researchers employed by Dutch Universities that comply with the legal requirements of Article $25 \mathrm{fa}$ of the Dutch Copyright Act are distributed online and free of cost or other barriers in institutional repositories. Research outputs are distributed six months after their first online publication in the original published version and with proper attribution to the source of the original publication.

You are permitted to download and use the publication for personal purposes. All rights remain with the author(s) and / or copyright owner(s) of this work. Any use of the publication or parts of it other than authorised under article $25 \mathrm{fa}$ of the Dutch Copyright act is prohibited. Wageningen University \& Research and the author(s) of this publication shall not be held responsible or liable for any damages resulting from your (re)use of this publication.

For questions regarding the public availability of this article please contact openscience.library@,wur.nl 


\section{Bee mietii rak rkabni nis (The people know how to seed water): A Zapotec experience in adapting to water scarcity and drought}

\section{Britt Basel , Nadir Hernández Quiroz , Roberto Velasco Herrera , Carmen Santiago Alonso \& Jaime Hoogesteger}

To cite this article: Britt Basel , Nadir Hernández Quiroz, Roberto Velasco Herrera , Carmen Santiago Alonso \& Jaime Hoogesteger (2020): Bee mietii rak rkabni nis (The people know how to seed water): A Zapotec experience in adapting to water scarcity and drought, Climate and Development, DOI: 10.1080/17565529.2020.1855100

To link to this article: https://doi.org/10.1080/17565529.2020.1855100

\section{曲 Published online: 14 Dec 2020.}

Submit your article to this journal 2

\section{Џll Article views: 21}

Q View related articles $\sqsubset$

View Crossmark data 


\title{
Bee mietii rak rkabni nis (The people know how to seed water): A Zapotec experience in adapting to water scarcity and drought
}

\author{
Britt Basel $\circledast^{\mathrm{a}, \mathrm{b}, \mathrm{c}}$, Nadir Hernández Quiroz ${ }^{\mathrm{d}, \mathrm{e}}$, Roberto Velasco Herrera ${ }^{\mathrm{f}}$, Carmen Santiago Alonso ${ }^{\mathrm{d}, \mathrm{e}}$ and \\ Jaime Hoogesteger $\mathbb{Q}^{\mathrm{c}, \mathrm{g}, \mathrm{h}}$
}

\begin{abstract}
${ }^{a}$ Ecothropic, Cimarron, Colorado, U.S.A; ${ }^{b}$ Ecothropic México A.C., Chiapas, México; ${ }^{C}$ Water Resources Management Group, Department of Environmental Sciences, Wageningen University, the Netherlands; ${ }^{\mathrm{d}}$ Coordinadora de Pueblos Unidos por el Cuidado y la Defensa del Agua (COPUDA); eEl Centro de Derechos Indígenas Flor y Canto A.C.; 'Unión de Comunidades y Ejidos Buin Dannis de la Cordillera Central Ocotlán Tlacolula (Buin Dannis) A.C.; ${ }^{9}$ Visiting researcher: Universidad Nacional Autónoma de México - Instituto de Investigaciones en Ecosystemas y Sustentabilidad, Morelia, México; ${ }^{\mathrm{h}}$ Department of Geomatic and Hydraulic Engineering, Universidad de Guanajuato, Guanajuato, México
\end{abstract}

ABSTRACT

We are facing a global water crisis exacerbated by hydro-climatic extremes related to climate change. Water scarcity is expected to increasingly affect indigenous and marginalized populations. Supporting the sovereignty of indigenous and rural populations to create water secure futures through placebased knowledge, local management, and Community-based Adaptation (CBA) measures may help tackle this crisis. Zapotec communities in Oaxaca, Mexico have self-organized for collective action to use Managed Aquifer Recharge (MAR) to address water scarcity, resulting in a perceived increase of groundwater availability. Treating groundwater as a common-pool resource (CPR) within a sociohydrological system, the objectives of this paper are two-fold: (1) to explore how MAR may be implemented as a CBA measure, and (2) to understand what factors triggered and/or enabled the widespread implementation of MAR by Zapotec indigenous communities in the Valles Centrales of Oaxaca, Mexico. In doing so, we aim to get a better understanding of local processes while also furthering theories that relate to CBA, CPR, and sociohydrology. This paper was born from the desire of the Zapotec community members to share their experience and lessons learned so other droughtvulnerable communities might benefit.
ARTICLE HISTORY

Received 17 June 2020

Accepted 17 November 2020

\section{KEYWORDS}

Sociohydrology; communitybased adaptation; collective action; managed aquifer recharge; indigenous knowledge; water security; Mexico; climate change; drought

\section{Introduction: community-based climate adaptation in the water sector}

\footnotetext{
"Water is the blood in the veins of our mother earth." - COPUDA member
}

We are facing a global water crisis (Gosling \& Arnell, 2013; Kummu et al., 2016; Rockström et al., 2014; Srinivasan et al., 2017; UN DESA, 2019). More than half the planet will be increasingly exposed to water scarcity and shortage (defined as the impacts of insufficient water availability to meet the needs of the local population, due to climate impacts, distributional inequities, and increasing demand) (Jiménez Cisneros et al., 2014; Kummu et al., 2016). Social, economic, and political conditions further exacerbate a population's vulnerability to water scarcity (Forsyth, 2017; Kahn et al., 2013). Inequitable access to resources, including water, can leave local populations dispossessed of agricultural lands, livelihoods, and cultural identity, while posing a threat to sustainable development and environmental distributional justice (Dell'Angelo et al., 2018; Mehta et al., 2012; Rodríguez-Labajos \& MartínezAlier, 2015; Zwarteveen \& Boelens, 2014). Top-down solutions for water provision (i.e. large-scale infrastructural and watershed projects) infrequently benefit indigenous populations, and often leave indigenous populations affected and dispossessed (Finley-Brook \& Thomas, 2010; Hidalgo et al., 2017; Hoogesteger \& Verzijl, 2015).
Amidst this context, indigenous populations often have place-based knowledge and generational experience in managing local resources and adapting to climatic variability (Basel et al., 2020; Berkes \& Armitage, 2010; Boillat \& Berkes, 2013; Reid, 2016). Local resource users may have the most knowledge of and incentive for effectively managing local resources, questioning notions that state management is the only or most effective strategy (Boelens \& Hoogesteger, 2017; Hoogesteger et al., 2016; 2017; Meinzen-Dick et al., 2002). Addressing the water crisis may therefore be aided by supporting the sovereignty and agency of indigenous and rural populations to create water secure futures through place-based knowledge, local management, and communitybased adaptation (CBA) measures (Falkenmark et al., 2007; Zeitoun et al., 2016). Adaptation, as defined by Few et al. (2007, cited in Dodman \& Mitlan, 2011, p. 2.), is "controlling the particular problem (decreasing its probability of occurrence); coping with the problem (reducing sensitivity to the problem); or avoiding the problem (limiting its potential effects)." CBA is then "based on the premise that local communities have the skills, experience, local knowledge and networks to undertake locally appropriate activities that increase resilience and reduce vulnerability to a range of factors including climate change" (Dodman \& Mitlin, 2011, p. 1), and is, "a community-led process, based on 
communities' priorities, needs, knowledge and capacities, which should empower people to plan for and cope with the impacts of climate change" (Reid et al., 2009, p. 13 cited in Reid, 2016, p. 4). Often framed as a development intervention (in which an external actor facilitates a population toward increasing resilience through initiatives) (Forsyth, 2017), this paper treats CBA as including bottom-up, community-driven actions. Community-driven actions are defined as actions taken through and by the initiative of local actors for the purpose of achieving adaptation outcomes (see Basel et al., 2020). Adaptation outcomes are achieved when measures successfully avoid, cope with, or control a problem; for example, successfully addressing resource challenges, such as water scarcity.

The current context of the water and climate crisis, social inequities, and the premise that local resource users are capable of adapting, suggest the utility of identifying CBA measures for the water sector. When identifying CBA measures, it is important to remember that "CBA is, by definition, contextual and place specific" (Forsyth, 2017, p. 12) and that communities are not homogenous units, but made up of individuals with varying needs and priorities (Rodima-Taylor, 2012). Additionally, all human use of and interaction with natural resources happens within a complex social-ecological system (Ostrom, 2009a): "there are no simple, definitive, or universal rules that govern these systems, because we will always have incomplete knowledge of them and their relations with larger systems" (Ostrom, 2009b, cited in Morçöl, 2014, p.14). Since CBA measures cannot be a "one-size-fits-all" approach, this paper aims to contribute to the literature by identifying factors that enable or inhibit CBA measures and result in successful adaptation outcomes in specific placebased and cultural contexts.

Exemplifying the social-ecological interplay explained by Savenije et al. (2014) in which ecological limits incite people to take action, twenty-two Zapotec indigenous municipalities (also referred to as communities) of the Valles Centrales of Oaxaca, Mexico self-organized into two separate and originally unarticulated associations to address water scarcity and its impact on local livelihoods. Municipalities in the mid Río Verde, Atoyac, and San Antonio-Río Tehuantepec watersheds organized to become the Unión de Comunidades y Ejidos Buin Dannis de la Cordillera Central Ocotlán Tlacolula A.C. (Buin Dannis), while municipalities in the lower Río Verde and Atoyac watersheds joined together to create the Coordinadora de Pueblos Unidos por el Cuidado y la Defensa del Agua A.C. (COPUDA), which receives pro-bono legal representation and support from the civil association El Centro de Derechos Indigenas Flor y Canto A.C. Independently, both associations have addressed water scarcity using low-cost and low-tech interventions for Managed Aquifer Recharge (MAR). Interventions consist of simple constructions designed to capture rainwater runoff, allowing water to infiltrate the soil and recharge groundwater that, in turn fills community wells with water for household and agricultural use.

Recognizing that CBA in the water sector occurs within a sociohydrological system, the goals of this paper are to: (1) explore how MAR may be implemented as a CBA measure, and (2) understand what factors triggered and/or enabled the widespread implementation of MAR by Zapotec indigenous communities in the Valles Centrales of Oaxaca, Mexico. Our analysis highlights multiple variables that have facilitated the self-organization of Zapotec communities. This paper is structured as follows: Section 2 describes the methods used; Section 3 briefly reviews and explores linkages between sociohydrology, community-based adaptation, common-pool resources, and managed aquifer recharge literature; Section 4 overviews the local context; Section 5 describes the Zapotec experience using MAR to address water scarcity; Section 6 identifies variables enabling self-organization; and Section 7 concludes the paper and identifies future research directions.

\section{Methodology}

Drawing on the methodology pioneered by Wester et al. (2011), this paper results from a critical dialogue among three local practitioners (the second, third, and fourth authors of this paper) and two external researchers (the first and fifth authors) about the direct experiences of these three practitioners as participants with leadership roles in the Zapotec experience with community-based Managed Aquifer Recharge. This methodology was chosen for allowing an approach (Forsyth, 2001) that emphasizes and honors the personal voices, cultural perspectives, and field observations of these three authors as local experts and practitioners.

The first author conducted two week-long field visits, over two sequential years, to orient research efforts within the cultural and social landscape of the communities in question. During these visits, starting with an established relationship with a Zapotec mezcal producer in Santa Catarina Minas, informal interviews $(n=22)$ were conducted using a snowball approach with civil associations working with water in the region and with urban and rural Oaxacans in the Valles Centrales. Drawing on these data and a review of publications relating to Managed Aquifer Recharge in newspapers and social media networks, key stakeholders (including the organizations Buin Dannis and COPUDA) were identified and mapped. The three local practitioners (collaborating as authors on this paper) were chosen because 1) they are recognized within Buin Dannis and COPUDA as legitimate and respected representatives of each association (respectively), 2) the leadership roles these individuals have had in community organization, design/construction of MAR infrastructure, and communications (scientific, legal, and media) about the Zapotec experience, and 3) the multi-faceted and direct engagement these practitioners have had with the communities in question. ${ }^{1}$ The topics discussed in the following sections draw heavily on their direct involvement in and focus on waterrelated themes, spanning from 1999 to the time of publication, in the Zapotec communities discussed in this paper.

Based on the data gathered from interviews, stakeholder mapping, field observations, and a review of existing documentation, the first and fifth authors drafted a semi-structured interview template aimed at corroborating initial findings and elucidating the cultural, social, legal, environmental, livelihood, historical, and ideological context of the communities in question. The practitioners (authors 2, 3, and 4) submitted written responses to interview questions which were then 
cross-analyzed in the context of available data/literature on the region. Over a period of five months, the first author then facilitated an iterative consultation with and between these local practitioners through recorded and written communications. Through this process, the five authors collectively and critically analyzed the studied experiences in light of the theoretical framework outlined in this paper. The process led to the joint understanding and analysis of the MAR experience - from both the Buin Dannis and COPUDA perspectives - that is presented in this paper.

\section{Sociohydrology, community-based adaptation and managed aquifer recharge}

CBA (centered around problems that affect human populations and the responses of these populations) in the water sector occurs within a social-ecological system, and is further nested within a sociohydrological system: humans influence water resources through behavior and infrastructural interventions. In turn, the availability of hydrological resources and hydro-climatic events influence human behavior and interventions, creating interplay and feedbacks between the two systems (Rusca \& Baldassarre, 2019). Di Baldassarre et al. (2019) propose that understanding the relationships between "natural, technical, and social processes" and resulting phenomena can improve water management and contribute to solving the global water crisis. Applying the sociohydrological lens to CBA in the water sector enables the design of governance structures (i.e. collaboration among stakeholders or management interventions) that are well-matched to the biophysical environment which, according to Bodin (2017), increases the likelihood of addressing resource challenges.

The socio-technical CBA intervention in hydrological processes analyzed in this article is Managed Aquifer Recharge (MAR). MAR refers to "a suite of methods that is increasingly used to maintain, enhance and secure groundwater systems under stress" (Dillon et al., 2019, p. 1), often through the injection or facilitated infiltration of water into an aquifer. The effectiveness of MAR for increasing groundwater availability is widely recognized (Malik et al., 2014; Patel \& Prabhakar, 2012; Renganayaki \& Elango, 2013; Rockström et al., 2014; Sadoff et al., 2015). The archeological record further demonstrates the use of MAR to increase long-term resilience to drought in Pre-Incan Peru, India, and Jordan (Kennedy, 1995; Malik et al., 2014; Ochoa-Tocachi et al., 2019; Pandey et al., 2003). Dillon et al. (2019, p. 3) explain "watershed management interventions such as contour bunds and check dams have been used for millennia in the Middle East, Asia and South America to detain monsoon runoff, to defend against soil erosion and conserve water, and as a by-product, groundwater recharge [is] increased." The International Groundwater Assessment Centre (n.d.), and recent studies (i.e. Guyennon et al., 2017; Shah, 2009) recognize that MAR can be used as an adaptation strategy to decrease vulnerability to climate change. However, there has been little study of MAR as a CBA measure for the water sector. Additionally, with few exceptions (i.e. Kennedy, 1995; Lasage et al., 2015; Lasage \& Verburg, 2015; Ochoa-Tocachi et al., 2019; and Pandey et al., 2003) the discussion of MAR for CBA has often been confined to journals on hydrology, and is seldom addressed within the field of CBA.

As a discipline, sociohydrology is still developing knowledge of the variables that drive system dynamics. While the literature on sociohydrology has called for hydrology to endogenize human agency (Di Baldassarre et al., 2019; Pande \& Sivapalan, 2017), defined as the capacity for humans to influence hydrological flows, either on purpose or unintentionally (Pande \& Sivapalan, 2017; Rusca \& Baldassarre, 2019), Troy et al. (2015) and Loucks (2015) discuss the need to further incorporate human behavior into sociohydrological models: the literature on common-pool resources (CPR) may help fill this gap.

Water is a CPR, defined as "resources for which exclusion of users is difficult to achieve and for which joint use reduces the availability of benefits derived from the resource for others" (Steins \& Edwards, 1999, p. 539). Hardin (1968) proposed that individuals have incentive to overexploit commonlyshared natural resources, undermining the possibility for sustainable resource management, and therefore justifying the top-down governmental or privatized control of CPR. Gardner et al. (1990) and others have since refuted this argument by empirically demonstrating sustainable management of socialecological systems and CPR through collective action: collaborative management of a shared resource by resource users. A significant body of literature on collective action has since been developed ${ }^{2}$ including examples of self-organization for collective action for management of groundwater resources (i.e. Bardhan, 2000; Hicks \& Peña, 2003; Ostrom, 2000; Van Steenbergen, 2006). The capacity for collective action is a determining factor in community adaptation to climaterelated challenges (Adger, 2003; Karim \& Thiel, 2017; Rodima-Taylor 2012).

Ostrom's research shows that specific characteristics of a resource and resource users increase the probability of selforganization for collective action for sustainable resource management (Ostrom, 2000; Ostrom, 2009a): (1) Size of the resource system (supplying a sufficient quantity of the resource; being of a realistic size to manage), (2) Productivity of the resource system (benefits justify management cost), (3) Predictability of system dynamics (effort invested will likely yield results), (4) Resource unit mobility (continued location in an area that can be managed), (5) Collective-choice rules (participative governance; autonomy to govern and defend the resource against others), (6) Number of users (suitable to group organization and resource management requirements), (7) Leadership/entrepreneurship (respected local leaders; innovation), (8) Norms/social capital (including shared values, trust, and reciprocity), (9) Knowledge of SES/mental models (shared knowledge of resource function), and (10) Importance of resource (highly valued resource). Underlying the characteristics presented by Ostrom, water resources are affected by both local and basin level management. The success of local level management is then dependent on the higher-level policies that determine hydrological flows and availability of water resources in the larger basin, as well as the level of sovereignty local resource users have to manage water. Bridging collective action and climate adaptation literature, Adger (2003) further affirms the importance of social capital, specifically 


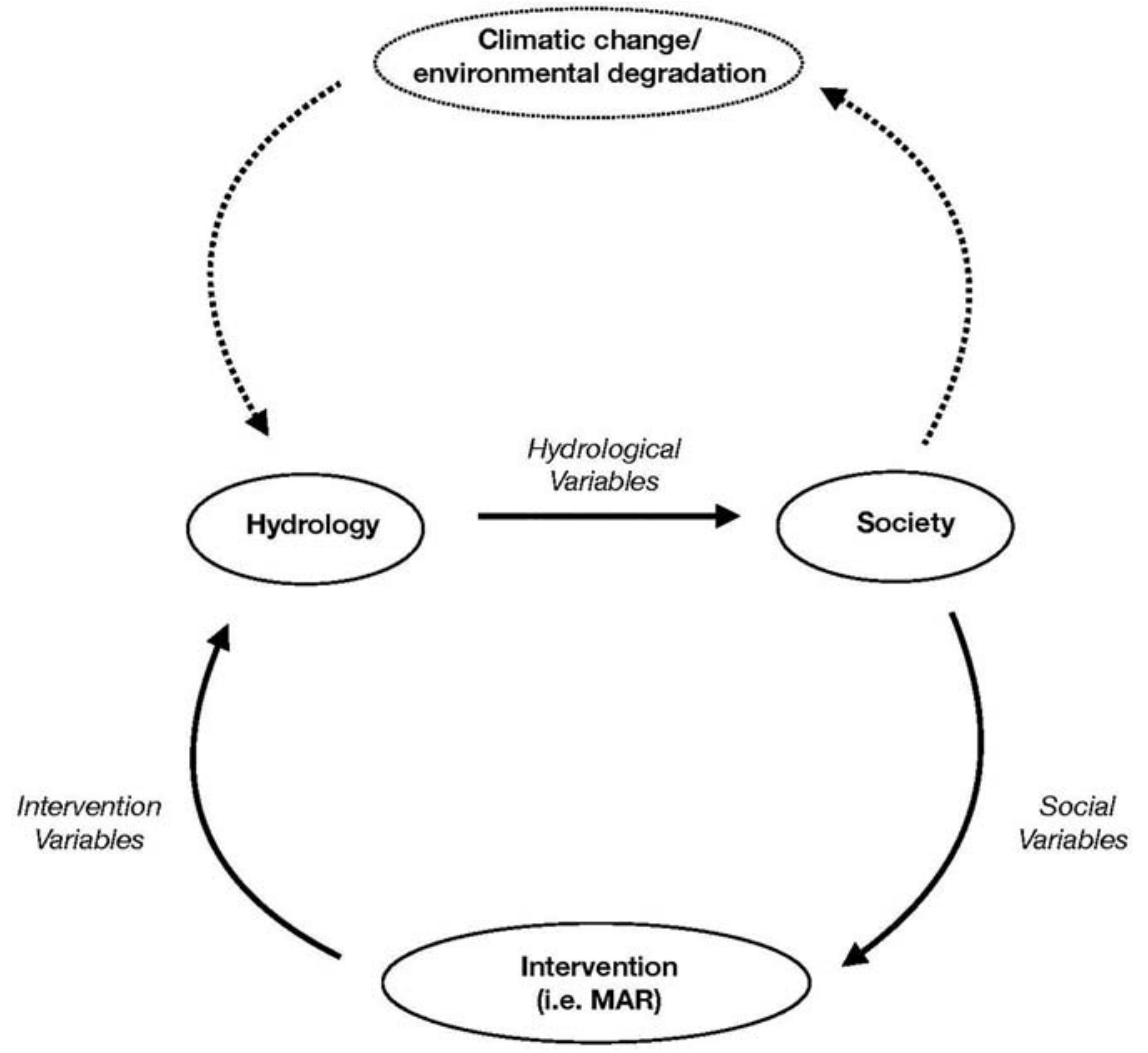

Figure 1. Authors' conceptualization of the sociohydrological process of community-based adaptation, based on Di Baldassarre et al. (2013), Di Baldassarre et al. (2019), and Rusca and Baldassarre (2019). Adaptation outcomes result when variables trigger a positive instead of a negative spiral.

reciprocity and shared values, in addition to benefit distribution, and climate-related risks (see also Hoogesteger, 2013; 2015). Upon this basis, we propose that CBA within a sociohydrological system requires accounting for the social (people and social structure influencing hydrology), technical (technologies used by society to influence hydrology), and hydrological (including geomorphology, ecology, and climate) variables (Figure 1).

In our analysis of CBA through MAR, we use these notions and focus especially on understanding what factors triggered and facilitated the widespread implementation of MAR by indigenous communities in the Valles Centrales of Oaxaca. In doing so, we aim to get a better understanding of local processes while also furthering theories that relate to CBA, CPR, and sociohydology.

\section{The social and environmental context: the Valles Centrales of Oaxaca}

\subsection{Geography and history}

The Valles Centrales of Oaxaca, in the southern Mexican highlands, are connected semi-arid valleys and foothills within the Sierra Madre mountains with a starting elevation of 4,790 feet. Higher elevations of the microregion can receive up to $4000 \mathrm{~mm}$ of annual rainfall, while the valley floor is in the rain shadow of the mountains, reducing annual rainfall to 400-800 mm (CONAGUA, n.d.; Flannery et al., 1967; GEAS A.C, 2011; Servicio Meteorológico Nacional de México, n.d.).
The area was originally populated around 8000 B.C.E, with 1500 B.C.E. seeing a shift from hunter-gatherer societies to early farming by peoples. Pre-Hispanic towns and ceremonial centers, including Monte Alban, primarily rose between 600200 B.C.E. (Flannery et al., 1967). Currently, the region is predominately populated with indigenous Zapotec, Mixtec, Mixe, and mestiza (of mixed indigenous and Spanish heritage) communities spread between growing urban centers.

Evidence suggests that pre-Hispanic populations of the region used MAR techniques. Flannery et al. (1967) discusses that while archeologists once believed the Valles Centrales had contained a large lake, as of 1967 this belief had been proven wrong. However, according to the experiences of the third author, indigenous legend tells of ancient bodies of water in the Valles Centrales. While legends do not specify whether bodies of water were natural or constructed, the third author shared that local people acknowledge that pre-Hispanic Mixteca created terraced structures within streams to increase soil moisture for crops and Zapotec ancestors captured rainwater; in the valley of Tlacolula, there is evidence of a check dam (a MAR technique which serves to create a reservoir) that was built approximately 430 years ago.

\subsection{Beliefs and cosmovision}

The interviews illustrate that the current Valles Centrales population is largely united through indigenous language and cosmovision. For the Zapotec people, language, cosmovision, and territory are pillars that orient cultural identity, expressing 
themselves across political and economic spheres and in daily life: working the land, artistic expression, culinary tradition, the use of flora and fauna, and religious festivals. Through shared identity, the Zapotec people maintain and defend their cultural and territorial rights. Because water is central to agriculture, territory, and therefore identity, and due to increasing concerns about drought and water scarcity, water has increasingly become a local concern that has triggered collective action.

According to the interviews, the abuelos (the grandparents) say Zapotec social organization constitutes the horcones de la sociedad, the supporting structure that shapes society: asambleas (community assemblies), tequio (cooperative, voluntary, and mandatory work), la gozona and la mano vuelta (voluntary work based on collaboration, reciprocity, and future exchange, either on the familial or community level), la gueza (community collaboration to supply for celebrations, i.e. corn, turkeys, or mezcal, with the understanding that by offering support now, individuals and families will later receive similar support), community celebrations, barter, and sharing. Given these cultural foundations, the protection of the environment, and especially the protection of water, is not an individualistic but collective process based on reciprocity.

In the Zapotec world view, reciprocity is further seen in how all aspects of nature serve to support the greater whole. Just as bees pollinate, benefiting flowers and humans, all beings, including humans, have an important role in a vast divine collaboration. There are also protectors known as the nahuales of the madre tierra (mother earth) - of the water, of the wind, of the light-with which humans constantly interact. To better understand this, the fourth author, as a Zapotec elder, suggests sitting close to a stream. Instead of looking at the stream as a resource, listen to the song of the water and form a relationship with the water. Then ask yourself about this being: "How was it that this water, born from a spring, has the strength to walk through creeks and find the rivers and meld with them to become one?"

From this perspective, humans have the responsibility to protect and care for these beings, just as these beings provide and care for humans and other creatures: environmental management is not a one-way relationship benefiting humans, but rather a reciprocal relationship that benefits all beings. The interviewees highlighted the Zapotec belief that individuals who understand reciprocity are responsible for transmitting this value to others, so they may also take care of each other and the madre tierra. Within such a cultural context of collective action and reciprocity, community members are naturally obliged to work together to protect and defend water.

\subsection{Agriculture and livelihoods}

Indigenous livelihoods in the region are focused on the production of milpa (a traditional agricultural system centered on intercropping maize, beans, and squash), agave production (for the production of mezcal, a distilled alcohol important for both cultural activities and export), vegetable production (both in open-air fields and in greenhouses), free-range cattle production, and flower production (for domestic and international markets). Agricultural and animal products are used for household subsistence and for commercial sale at markets in nearby municipalities.

For early and modern agriculturalists, livelihoods have been made possible by an unconfined aquifer and shallow water table, averaging 3-6 feet below the surface (Flannery et al., 1967). As far back as 700 B.C.E., families dug shallow wells at intervals among their fields and used riego a brazo, (potirrigation) where a 3-gallon jug is used to water each plant with water from the shallow wells (ibid). This technique was used until recently by Zapotec peoples and has traditionally allowed for three annual corn (maize) harvests on the valley floor and two corn harvests on the slopes of the valley. Modern irrigation features riego rodado where water is gravity fed from small reservoirs or drawn from wells to shallowly flood the agricultural plot. Starting in the 1990s, producers have increasingly used pumps to draw water from wells for this purpose.

\subsection{National groundwater governance context}

In Mexico, the Civil Code of 1884 recognized the right of land owners to prospect for and use groundwater, legally opening the doors for individuals to invest in groundwater development. In 1945, paragraph 5 of Article 27 of the Mexican Constitution was amended to give the federal government the right to intervene in groundwater management:

... when it is in the public interest or if it affects the supply of other users, the country's President [through the Federal Government] may regulate its [groundwater] extraction and utilization, and even establish prohibited areas [veda], in accordance with that which applies for other waters of national property (Delgado Moya, 1999, p. 49).

According to the Water Law of 1972, in areas under veda it is only allowed to sink new (tube) wells with the prior consent of the national water authority, but the implementation of these regulations is weak (Hoogesteger \& Wester, 2017). This has led to a situation in which the National Water Commission (CONAGUA) can legally intervene in groundwater regulation, but due to a lack of administrative capacity, aquifer overdraft is widespread, especially in the center and north of the country (Hoogesteger, 2018).

Since 2004, the figure of Technical Groundwater Committees (Comités Técnicos de Aguas Subterraneas (COTAS)) is recognized in the National Water Law (LAN, 1992). They are defined as civil society organizations whose membership is made up of groundwater users from all water use sectors of one aquifer (Wester et al., 2009; 2011). Legally COTAS are recognized as auxiliary civil society organizations that support and participate in the river basin councils (presided by CONAGUA). Their role is as advisors, supporting the design and implementation of programs and plans for sustainable aquifer management (LAN, 1992 article 14 BIS). However, in most aquifers, especially in the south of the country, no COTAS have been created. Therefore, in these areas, including the Valles Centrales, there are no formal organizations that function as interlocutors between organized groundwater users, the respective river basin councils, and CONAGUA. 


\subsection{Federal government interventions in the Valles Centrales}

In 1967, Mexican President Gustavo Díaz Ordaz imposed a "veda" or ban on groundwater use for the Valles Centrales (DOF, 1967). The act was justified as a measure to conserve water for future generations. COPUDA members that remember 1967 recall that there was abundant water at the time and do not see any justification for the ban. They also point out that in 1985, the state and federal government started to drain the wetlands of the Valles Centrales to build roads. COPUDA members relate these infrastructural changes to the beginning of the drought and to the expansion of area used for agricultural production which results in greater water use (Centro de Derechos Indígenas Flor y Canto, n.d).

\subsection{Collective versus privatized resource governance}

Indigenous communities in Mexico are given special legal status permitting autonomy and self-governance according to Usos y Costumbres (Uses and Customs) provided no conflict with the Mexican Constitution (Gamboa Montejano \& Valdés Robledo, 2018). While indigenous populations may be granted communal lands, the state retains rights to natural resources. Groundwater is the property of the Mexican government which cedes the private right (titulo de concesión) to use water through water concessions. The concession title allows the owner/user to extract a certain volume of water per year for a period between five and fifty years with an average of ten, after which the concession title expires and needs to be renewed. Private concession titles are granted and administered through CONAGUA and registered in the Public Registry of Water Rights (REPDA). The procedures, rights, and obligations attached to water concessions are established in Articles 20-29 of the National Water Law and its amendments (LAN, 1992).

In stark contrast to the highly centralized and bureaucratic national water governance institutions and regulations, Zapotec governance structure is based on elected local leaders who hold positions for three-year terms and community consensus achieved through asemblea (mandatory community meetings in which representatives from each household are consulted about all major decisions, including land management, municipal plans, and legal statues).

The third and fourth authors assert that government has attempted to divide the collective spirit of indigenous people by privatizing previously communal lands and water. Their experience, corroborated by others including Hoogesteger and Rivara (2020), Martínez Coria and Haro Encinas (2015), Hall (2015) and Trawick (2003) indicates that privatization facilitates the fragmentation and sale of communal and indigenous territory, the disintegration of community structure, and commercial exploitation of natural resources. Conversely, communal land tenure signifies a collective of owners, lending to a larger group able to defend local interests against government, transnational corporations, and others through collective action.

Indigenous movements to defend resource rights have figured prominently in Mexico's history (Carruthers, 1996;
Martin et al., 2011). COPUDA communities, in addition to implementing MAR, have united in legal action against the government for a collective right to water. Their collective action was in response to CONAGUA sanctioning COPUDA communities for water use (justified by the 1967 Federal water ban which had been unknown to communities). As a leader of the initiative, the fourth author asserts that social organization within and among communities has been a prerequisite for confronting the Mexican government and addressing the complexity of water scarcity, creating a feedback loop that further fortifies unity and the capacity for self-organization among COPUDA communities.

\subsection{Natural resources and observed climate impacts}

Due to the Zapotec cosmological relationship with natural resources and the importance of groundwater to local livelihoods, local concerns about water scarcity have increased as communities have experienced changing rains, drought, and dropping groundwater levels. The interviews indicate an observed increase in average temperatures and consensus that rainfall has decreased since 1970-1980. The rainy season no longer aligns with the traditional agricultural calendar, with rains beginning one to two months later than expected and falling sporadically rather than predictably. These observations are supported by a calculated average of meteorological data showing a decrease in precipitation for 1981-2010 as compared to $1971-2000$ of $9.7 \%$ for COPUDA communities and $6.7 \%$ for Buin Dannis communities (CONAGUA, n.d.; Servicio Meteorológico Nacional de México, n.d.).

The interviews further elucidate that the Zapotec communities began to experience water scarcity in the mid-1980s. On the valley floor, farmers observed agricultural soils had gone dry. In the foothills, farmers could no longer produce two annual harvests, impacting livelihoods. There was insufficient water to meet the needs of people and livestock. In 2005, the people faced the height of the drought with continually dropping water levels in wells. With unpredictable rains, dropping groundwater levels, and the high financial investment required for planting, numerous Zapotec producers abandoned agriculture. Many people migrated to urban centers and to the U.S. in search of work, with drought-related migration reaching a peak in 2006 (Centro de Derechos Indígenas Flor y Canto, n.d; Grupo Mesófilo A.C., 2012; Grupo Sturnira Oaxaca S.C., 2011a; Grupo Sturnira Oaxaca S.C., 2011b; Grupo Sturnira Oaxaca S.C., 2011c; Grupo Sturnira Oaxaca S.C., 2011d; Unión Buin Dannis, 2011). One community member shared, "There are communities without men or youth, because they all migrate, because they have had to abandon planting due to the lack of water" (Santiago Alonso et al., 2011).

Natural resources in the Valles Centrales have also been heavily exploited. Changing land use, mining activities, unregulated timber harvest, overgrazing, and habitation fragmentation have resulted in high biodiversity loss and compromised ecosystem services (Primack et al., 2001). Interviewees highlight that mining activities, which draw on the same aquifer as Buin Dannis and COPUDA communities, further increase the demand on water resources, while contaminating 
groundwater and dividing communities with unreliable promises of financial gain at the cost of environmental degradation. Interviewees observed that rivers, and the water quality of groundwater in the region, are further compromised by untreated sewage, indiscriminate use of agrochemicals, and trash; high microbial levels impact public health (Rowles et al., 2018).

Deteriorated ecosystems have reduced resilience to natural disasters, including floods and droughts (GEAS A.C, 2011). The political and social marginalization of Zapotec communities limit development opportunities, resulting in increased pressure on natural resources and a vicious cycle in which the future of present and future generations is at risk (ibid). As stated by a community member of COPUDA, "If we are left without water, the people will disappear and only a desert will remain."

\section{Managed aquifer recharge as a community- based adaptation measure: changing the sociohydrology of the Valles Centrales}

\subsection{Unión de Comunidades y Ejidos Buin Dannis de Ia Cordillera Central Ocotlán Tlacolula A.C. (Buin Dannis)}

According to the personal experiences of the third author, community leaders began to coordinate local actions to address water scarcity in 2005. In 2010, the consortium was formalized as Buin Dannis A.C. (meaning "people of the hills and water") to organize interventions to address water scarcity in each participating community. As networked communities (Figure 2) with a shared watershed management strategy, Buin Dannis receives prioritized access to government funding for water initiatives. Representatives of the association are integrated into existing governance structures of participating communities. Community asembleas also supply the forum for proposing interventions and providing work updates. Once approved by the asemblea, tequio is required of community members. Individuals who do not participate in tequio may not receive approvals or support when they make future requests of local leaders. Communities with a culture of government handouts have joined Buin Dannis, and later left the association upon understanding that participation requires shared work to address water challenges..

As the original Technical Director of Buin Dannis, the third author explains that MAR initiatives draw on traditional knowledge, paired with scientific and technical data to interpret the geomorphology and hydrogeology of the microwatersheds. MAR techniques have included: barreras de piedra acomodada and barreras vivas (on-contour low walls of stacked stone or planted vegetation); zanja bordo (continuous on-contour swales or ditches); zanja trinchera (short trough ditches dug on-contour at regular intervals); and retenes (small dams built from compacted earth or cement). These watershed management techniques reduce erosion caused by runoff, catch sediment, intercept rain runoff, increase the infiltration of rainwater, and facilitate reforestation by increasing soil humidity (Herencia de Restauración Forestal, 2006). Check dams (small dams built across runoff channels to slow water) have strategically been built across ravines for similar purposes. These small dams create micro-reservoirs which fulfill the double purpose of aquifer recharge and increasing surface water availability. More information on these

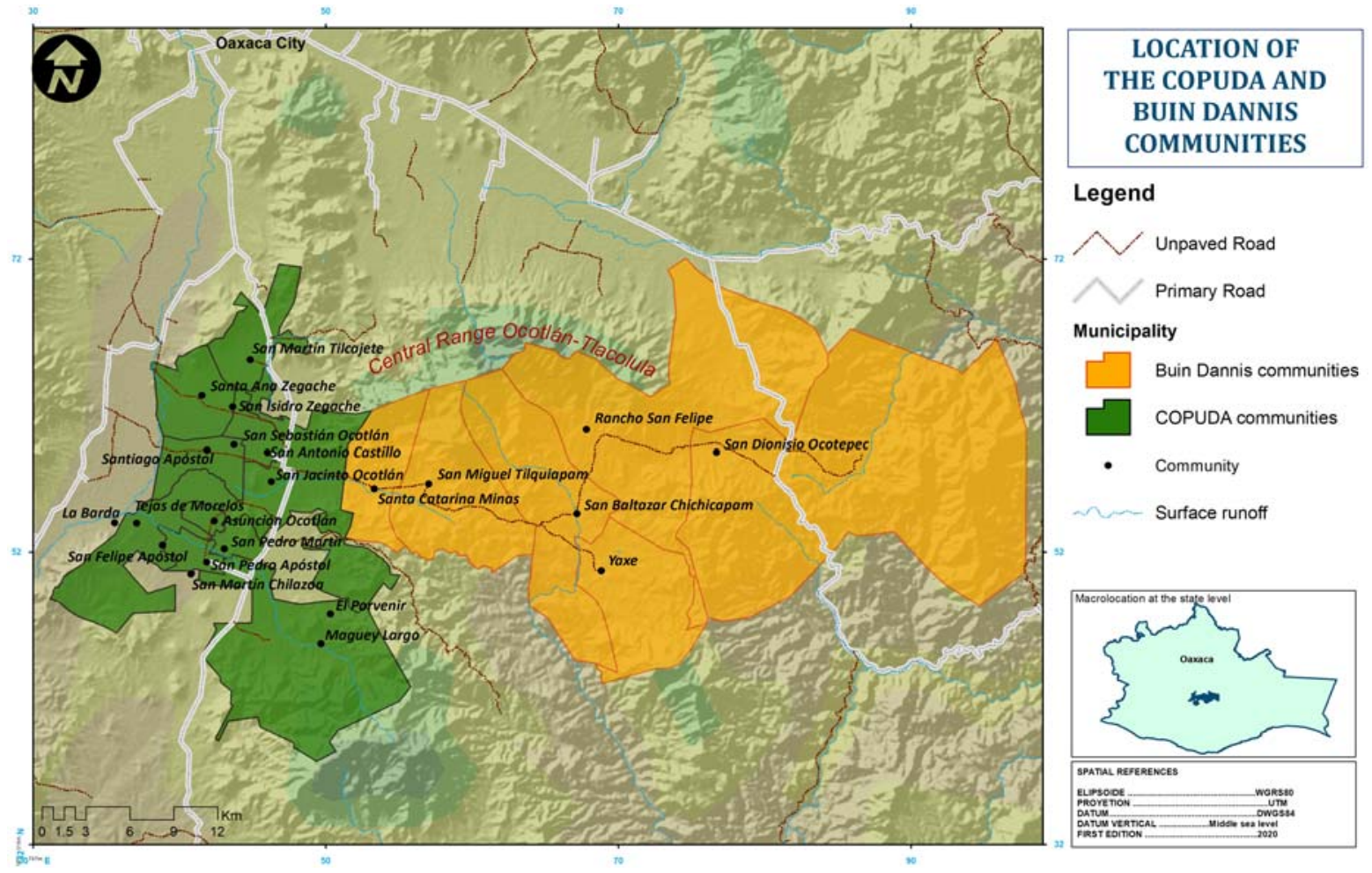

Figure 2. Location of the 22 COPUDA and Buin Dannis communities implementing Managed Aquifer Recharge. Santa Ana Zegache participates in both associations. The yellow and green zones indicate the territory under Buin Dannis and COPUDA management. 
techniques can be found in FAO (2000) and Herencia de Restauración Forestal (2006).

In combination with MAR, communities have reforested and established agroforestry systems using native species on approximately 1500 acres. Reforestation and the establishment of agroforestry systems has been on-contour with the intention of reducing erosion, protecting soil nutrients from runoff, and increasing soil humidity (Velasco Herrera, 2014).

The third author partially attributes Buin Dannis' success to planning activities sequentially. For example, before initiating a reforestation effort, community members might construct a check dam which would then supply water for irrigating the saplings.

\subsection{Coordinadora de Pueblos Unidos por el Cuidado y la Defensa del Agua (COPUDA)}

According to the second and fourth authors, communities of the Valle de Ocotlán (within the Valles Centrales) (Figure 2) joined in resistance and organized as COPUDA (Coordinator of United Communities that Stand for the Protection and Defense of Water) as a response to two simultaneously occurring circumstances in 2005: (1) a continually intensifying experience of drought which negatively impacted agricultural livelihoods, and (2) fees and fines levied by CONAGUA for water use, paired with institutional barriers to receiving government financial aid (Santiago Alonso et al., 2011). As one member shared, "May it be very clear that water is not merchandise. Water is a natural good and the government has not spent one cent to be able to say, 'Look, I'm making water, and that's why I'm going to sell it to you"' (CDI Flor y Canto A.C., 2018). While conflict over water rights was an important factor in the unification of COPUDA communities, interviews indicate that MAR activities are not a result of the conflict with COPUDA, rather MAR is parallel to this conflict and driven by a shared need to address water scarcity.

COPUDA is a network of community-level committees, represented by a Board of Directors that, like Buin Dannis, engages communities through participation in asembleas and in coordination with local government leaders. COPUDA attributes the association's success to the strategy of community-level committees which permits COPUDA to be rooted in each community, and from these roots, extend to incorporate additional communities (Santiago Alonso et al., 2011).

According to the interviews, COPUDA efforts have concentrated on (1) protecting and recharging the aquifers in the region through MAR techniques, (2) rainwater capture from roofs, (3) the separation of trash into organics, recyclables, and waste, (4) local awareness and capacity building about the defense of water, and (5) working with authorities and government to address community challenges while also demanding respect of indigenous lands and access to resources, including an exemption from the 1967 water ban.

The fourth author explains that MAR techniques used by COPUDA are inspired by, and derived from, techniques COPUDA representatives observed while visiting the Museo del Agua (Water Museum) in Puebla, which showcases preHispanic techniques for water management. Representatives visited the museum looking for techniques to mitigate the effects of the mid-2000s drought. Based on the techniques observed, COPUDA communities have constructed an estimated 350 check dams, infiltration wells, and ollas (unlined excavated "pools" built in areas with high runoff and low soil permeability) to capture surface runoff and allow water to slowly percolate into the soil, recharging groundwater and directly benefiting approximately 10,000 individuals across 16 communities.

\subsection{Tequio and collective action}

In the experience of both organizations, work done by individuals (versus shared work) increases the costs, increases social isolation, and can be demoralizing. As a result, water has been addressed collectively through tequio (shared voluntary labor). According to the interviews, tequio has involved the greater community with water management, generating increased awareness and personal investment in protecting water resources. Tequio also reduces costs, making MAR financially accessible. Funding for MAR activities has come from community-generated funds, agricultural authorities, municipalities, state and federal agencies, non-governmental organizations, and foundations. Interviews indicate that when community funds are combined with external support, the organizations have been able to benefit a larger population.

\subsection{Ceremony}

According to the personal experiences of the second, third, and fourth authors, both organizations have revitalized and emphasized performing pre-Hispanic ceremonies to ask permission of the deities of the earth and water before building each MAR structure. Offerings of foods, drinks, and wild plants are made to the nahual (guardian) that protects the site. Ceremonies symbolize reciprocity between human and nature, recognizing the integral role humans play in contributing to the functioning of nature: akin to bees pollinating, the people are "seeding water."

The fourth author believes ceremonies have fortified Zapotec identity and connection to territory within participating communities. She has observed that many community members have "re-found" Zapotec spiritual values, and believes this has given the defense of water a deeper spiritual significance, while reigniting trust in traditional practices. The interviews additionally show that ceremonies create an opportunity for elders to share their cosmovision with new generations; the same generations that have been increasingly distancing themselves from their Zapotec cultural roots.

\subsection{Youth involvement}

Interviews indicate that youth are gradually abandoning their communities and work in agriculture to pursue other aspirations. In the case of COPUDA, youth have only minimally participated in MAR activities. The weight of, and responsibility for, the defense of water has fallen primarily on adults, and largely on the elderly. Given the generational divide, the second and fourth authors question whether future generations will continue to work with MAR and to defend water. 
In Buin Dannis communities, youth have participated in MAR activities. The third author has observed that in asemblea, youth tend to argue in favor of projects that benefit biodiversity and water while proposing that MAR benefits both future generations and generations that are currently living the problem.

\subsection{Observed impacts of MAR}

To date, neither organization has quantitatively measured the hydrological impact of MAR activities. The third author has observed that rivers that had been dry since the 1990s have begun to seasonally flow again. The interviews elucidate that all communities have observed an increase in groundwater availability, attributed to MAR, resulting in perceived sufficient water for farming, household use, and livestock, even during the dry season. Agriculture and livelihoods have recovered, "... at least since we started this movement in which we started to build water harvesting structures, we have had water, until now we have not suffered from scarcity" (CDI Flor y Canto A.C., 2018).

Interviewees agree that MAR initiatives have become a unifying and orienting force for some communities. MAR projects have also resulted in additional benefits including aquaculture systems and recreational spaces. Interviews highlight that neighboring communities have replicated MAR after witnessing MAR impact on groundwater levels in wells.

The process has not been without challenges. The continuity of local MAR projects can be threatened by three-year terms for community authorities because new leaders may not understand the benefit of MAR or seek to financially benefit from construction. Projects must be well-designed and accurately account for the costs from the beginning. Increased water availability has permitted increased agricultural production, posing a new challenge of increased water and agrochemical use, which in turn pollutes water resources. While water usage has been occasionally regulated by committees or families, resulting in internal governance, regulation of water use is not yet a common practice among communities.

\section{Discussion}

A qualitative analysis of the Zapotec experience elucidates several social variables and sub-variables (Figure 3 ) that have triggered and/or enabled self-organization to use MAR as a CBA measure, and facilitated the perceived adaptation outcome of reduced water scarcity.

\subsection{Social variables}

\subsubsection{Collective-choice rules}

Given the nested nature of institutions and the fluid boundaries of water resources, many factors are beyond community control. Collective-choice rules, in which natural resource management is governed by group consensus, is inhibited by larger-scale institutions allowing urban populations, private interests, and mining operations to use and contaminate shared water resources. Federal ownership of water resources impinges local water access rights and resource governance. In contrast, usos y costumbres supports autonomy and, despite threats of privatization, communal land rights also support self-organization for collective action. Additionally, the organization of communities into a larger network has increased institutional representation and successfully mitigated inhibiting policies (i.e. the water ban) while facilitating access to multi-lateral support, including scientific data, legal counsel, financial resources, and tools/machinery for MAR construction. Local governance through asemblea epitomizes collective-choice rules providing direct participation in resource management decisions.

\subsubsection{Number of users}

Ostrom (2009c) illustrates the number of users must be small enough for groups to reach consensus and individuals to feel that their contribution makes a difference. Meanwhile, groups must be sufficiently large to accomplish necessary tasks while fitting within the carrying capacity of water resources. Hydrological data pending, qualitative data suggests the number of users is appropriate for local water resource availability, accounting for current population, extractions, MAR, and livelihood activities. Additionally, the organizational structures emphasize community-level sovereignty within the greater management network, adjusting the number of users to targeted locations. These factors are further facilitated by: (1) an adequate number of networked communities to access government support, (2) sufficient population in each community to contribute to tequio, and (3) small enough populations for direct dialogue in asemblea.

\subsubsection{Leadership/entrepreneurship}

MAR for CBA has been rooted in established and respected governance systems. Echoing Levin (1992), leadership in COPUDA and Buin Dannis has involved both influential individuals from the local area and college graduates. The use of MAR additionally signals the presence of entrepreneurship and openness to new ideas. Lack of continuity in leadership (3-year terms) however, threatens uninterrupted participation of communities.

\subsubsection{Norms/social capital}

Initiatives benefit from strong and pre-existing social organization, rooted in shared cultural identity, in communities. Social structure, cosmology, and revitalized ceremonies now performed with MAR highlight and socialize reciprocity (both between people and with nature). Stemming from these shared cultural underpinnings, shared voluntary labor, further reflecting a culture of reciprocity, has reduced construction costs, while educating and engaging community members (supporting knowledge of the SES and collectivechoice rules). Norms and social capital facilitate cultural continuity when connecting present and future generations: youth emigration has threatened a shift in cultural identity and the agricultural character of the region, threatening decreased social capital (through shared identity) and compromised food sovereignty (also important to Zapotec cultural identity), and, as a consequence, menaces indigenous autonomy. Given how MAR has been linked to cultural identity, the involvement 


\begin{tabular}{|c|c|}
\hline \multicolumn{2}{|c|}{ Social Variables for Enabling Self-Organization } \\
\hline Variables (Ostrom, 2009a) & Sub-Variables \\
\hline Collective-choice rules & $\begin{array}{l}\text { - Political autonomy } \\
\text { - Political representation } \\
\text { - Communal land and resource rights } \\
\text { - Access to information for resource governance } \\
\text { - Tools for resource governance } \\
\text { - Funding for resource governance }\end{array}$ \\
\hline Number of users & $\begin{array}{l}\text { - Small enough population for individuals to feel that their } \\
\text { contribution makes a difference } \\
\text { - Small enough populations for direct dialogue in } \\
\text { decision-making } \\
\text { - Matched to specific context and water balance } \\
\text { - Local sovereignty within organized management } \\
\text { network } \\
\text { - Adequate number of networked communities to access } \\
\text { government support } \\
\text { - Sufficient population to contribute to voluntary labor }\end{array}$ \\
\hline $\begin{array}{l}\text { Leadership/ } \\
\text { entrepreneurship }\end{array}$ & $\begin{array}{l}\text { - Rooted in established/respected governance systems } \\
\text { - Openness to new ideas } \\
\text { - Continuity in leadership }\end{array}$ \\
\hline Norms/social capital & $\begin{array}{l}\text { - Shared values } \\
\text { - Culture of reciprocity between people } \\
\text { - Culture of reciprocity between people and nature } \\
\text { - Shared voluntary labor } \\
\text { - Youth involvement }\end{array}$ \\
\hline $\begin{array}{l}\text { Knowledge of SES/mental } \\
\text { models }\end{array}$ & $\begin{array}{l}\text { - Generational/place-based experience with groundwater } \\
\text { - Access to information } \\
\text { - Varied sources of information } \\
\text { - Space for dialogue } \\
\text { - Participation in MAR construction }\end{array}$ \\
\hline Importance of resource & $\begin{array}{l}\text { - Economic importance } \\
\text { - Social /cultural importance }\end{array}$ \\
\hline Additional social variables & $\begin{array}{l}\text { - Population unified by a shared challenge } \\
\text { - Shared belief in the viability of rescuing the resource } \\
\text { - Small and short-term wins in an iterative process } \\
\text { - Access to financial resources necessary } \\
\text { - Access to physical resources necessary } \\
\text { - Equitable distribution of benefits }\end{array}$ \\
\hline Inhibiting social variables & $\begin{array}{l}\text { - Markets mechanisms dividing communities } \\
\text { - "Fixes that backfire" }\end{array}$ \\
\hline
\end{tabular}

Figure 3. Social Variables for Enabling Self-Organization for the use of Managed Aquifer Recharge as a Community-based Adaptation measure by COPUDA and Buin Dannis communities in the Valles Centrales of Oaxaca, Mexico.

of youth in MAR and agriculture (made possible by MAR) may support maintenance of Zapotec identity and sovereignty in the region, in addition to the continued use of MAR to manage water security.

\subsubsection{Knowledge of SES/mental models}

Generational experience irrigating with groundwater implies local familiarity with basic groundwater dynamics. Access to information on MAR, drawn from the Museo del Agua, technical support, and observed pre-Hispanic structures, has allowed an understanding of how MAR could shape hydrological flows to address local water scarcity. Community knowledge of MAR and the sociohydrological system has further been supported by asemblea creating a space to dialogue about issues. Increased knowledge through participation in MAR construction has created a positive feedback loop, increasing community capacity to further implement MAR and address water scarcity.

\subsubsection{Importance of resource}

In the Valles Centrales, water is a key economic and social resource central to cosmology, cultural identity, agricultural livelihoods, and food sovereignty. As a result, water scarcity drove emigration, affecting social capital. 


\subsubsection{Additional social variables}

Communities were unified by the shared challenge of water scarcity that, because of other variables (i.e. strong leadership and knowledge of the SES), individuals collectively believed could be viably overcome with collective action. The belief of community members in the viability of MAR was further fortified by small and short-term wins and sequential action during the implementation of MAR. Self-organization was supported by having the necessary resources to act: MAR initiatives have been financially enabled through (1) organizing to access governmental and non-governmental financial support and (2) reduced costs through voluntary labor. While hydrological measurements are necessary to evaluate the equitable distribution of benefits, continued efforts of communities suggest sufficient benefits received to justify the energy invested.

Market mechanisms may also undermine collective action: corporate promises that some community members will financially benefit from mining operations has divided some communities. Internal community division undermines collective action, inhibiting adaptation outcomes.

Recognized sociohydrological phenomena may also affect self-organization and inhibit positive adaptation outcomes. For example, in the supply-demand cycle (and more specifically the "fixes that backfire" sub phenomenon) increased water availability leads to greater water use (Di Baldassarre et al., 2019; Gohari et al., 2013; Kallis, 2010). In the Valles Centrales, increased water availability has facilitated increased agricultural production, which may further increase water use, eventually exceeding sustainable limits and resulting in water shortage. Increased production has also increased agrochemical use, contaminating water resources. This "fix that backfired" may be addressed through budding family- and community-level water use regulation. Furthermore, increased mezcal production (enabled by increased water availability and driven by rising domestic and international demand) appears to have resulted in improved livelihoods and decreased emigration. Conversely, production requires water and firewood for distillation, and harvesting of wild varieties of agave, negatively impacting hydrological resources and biodiversity. Finally, MAR initiatives hydrologically benefit downstream users including urban centers. Increased groundwater availability may result in increased use by downstream populations, and, cyclically, in compromised water availability for COPUDA and Buin Dannis communities. This phenomenon reaffirms the importance of collective-choice rules (including larger-scale governance institutions supporting local-level initiatives (Ostrom, 2009a)), knowledge of the SES, and leadership.

\subsection{Intervention variables}

Successful self-organization for MAR as a CBA measure further depends on variables related to the infrastructure used, including appropriate MAR design for the specific social and hydrological characteristics of the system and access to construction materials. Planning activities in succession so the completion of each activity created the resources necessary for the subsequent activity has been helpful. Further study of characteristics and utility of specific MAR interventions for CBA is necessary.

\subsection{Hydrological variables}

Addressing the quantitative analysis called for in sociohydrology (Rusca \& Baldassarre, 2019), Ostrom (2009a) proposes that the Size of the resource system, Productivity of the resource system, Predictability of system dynamics, and Resource unit mobility further determine the likelihood of self-organization. Within a sociohydrological system, consideration of geomorphology, meteorological data, projected climatic variability, ecology, water balance, and population growth, among others factors is also necessary. While quantitative analysis of these variables is beyond the objectives of this article, MAR has been made hydrologically possible by an unconfined aquifer and a shallow water table, while wetland deterioration in the 1980s may have reduced natural aquifer recharge and groundwater levels.

\section{Conclusions}

We are facing a global water crisis fueled by hydro-climatic extremes related to climate change. Water scarcity is expected to increasingly affect indigenous and marginalized populations. Systematic environmental distributional injustice is globally prevalent. There is a paucity of representation of indigenous knowledge in adapting to climate change and hydro-meteorological extremes. Within this complex context, twenty-two Zapotec communities have used MAR to address water scarcity.

The analysis of the Zapotec experience indicates MAR resulting in a perceived increase of water availability in the basin, forming an important addition to the discussion and theorization of sociohydrology and the practical application of MAR as a CBA measure. Further research is required to quantitatively assess how collective action for MAR has, and is, changing hydrological flows in these catchments. Further study is also necessary of Intervention and Hydrological Variables that support self-organization for, and the utility of, MAR as a CBA measure in diverse contexts.

The qualitative application of Ostrom's variables for selforganization has brought to light several enabling sub-factors (Figure 3) for self-organization for MAR as a CBA measure in the Valles Centrales. Variables that enable self-organization interact in a non-linear fashion where a small shift in one variable may cause significant shifts in other variables. Furthermore, while establishing rules is necessary for self-organization, rules must be adapted over time, accommodating changing local conditions (Ostrom, 2009c). Variables and governance rules must additionally account for increasing hydro-climatic variability.

There are no blueprints for the sustainable governance of all social-ecological systems (Ostrom et al., 2007). It would be erroneous to suggest that any CBA measure for the water sector could be a panacea. However, these variables have facilitated self-organization in diverse geographical and cultural contexts (Ostrom, 2009a). Understanding the factors that have enabled Buin Dannis and COPUDA to self-organize may support other communities in their own processes of self-organization to respond to our shared water crisis. 
Members of COPUDA and Buin Dannis hope that sharing their experience will benefit First Nations people and urban administrators alike, and that others may successfully follow in their footsteps.

\section{Notes}

1. The second author is the Assistant Director of Flor y Canto, A.C With COPUDA, he has participated in round-tables, meetings among community representatives, field visits, interviews, and has produced communication materials about the COPUDA experience. The third author has been a Technical Advisor for Buin Dannis, participating in processes of community organization, capacity building, and planning/construction of MAR infrastructure, since the inception of the association. The fourth author is a community member of the COPUDA community San Antonino Castillo Velasco. She is a co-founder of COPUDA and the Director of Flor y Canto, A.C. She has been directly involved in all legal action on behalf of COPUDA, as well as COPUDA's formation, development, and actions (including MAR).

2. As of 2020, a literature search for "collective action" and "Ostrom" yielded 86,800 results.

\section{Disclosure statement}

No potential conflict of interest was reported by the author(s).

\section{Notes on contributors}

Britt Basel is the founder and principle of the organization Ecothropic. She has extensive field experience as a practitioner and as a Technical Expert in Climate Adaptation and Disaster Risk Reduction in Oceania, Latin America, and the Caribbean. With an MSc in Human Dimensions of Natural Resources, and as a $\mathrm{PhD}$ Candidate researching adaptation measures to increase water security in the context of climate change, she specializes in culturally-appropriate, community-driven, and nature-based solutions.

Nadir Hernández Quiroz is the Assistant Director of the Center for Indigenous Rights Flor y Canto A.C. and supports 16 communities in the Valles Centrales in the protection and defense of water. He has collaborated with various organizations including non-governmental organizations and different institutions within the Mexican government. His primary activities are related to awareness and communication about the rights of indigenous peoples, indigenous culture, and indigenous territory.

Roberto Velasco Herrera is a MSc in Transportation and Distribution Systems, he has been a Technical Advisor to the Buin Dannis communities since the organization was created. He has participated in environmental impact studies and the development of community territorial plans throughout the Valles Centrales. He specializes in soil restoration and rainwater harvesting at the community and household levels.

Carmen Santiago Alonso has been a defender of Indigenous Rights in Oaxaca for the last 40 years. Her path started with protecting native languages and land rights. Since, she has participated in different processes of territorial defense with multiple municipalities across the Mexican state of Oaxaca. Currently she is the Director of the Center for Indigenous Rights Flor y Canto A.C. Since 2005, she has accompanied and given counsel to 16 Zapotec communities in the Valles Centrales in the social movement to protect and defend water against drought and to gain recognition of community-based water management.

Jaime Hoogesteger is an Assistant Professor at the Water Resources Management Group of Wageningen University in The Netherlands and is a visiting researcher at the Departamento de Ingenierías, Universidad de Guanajuato, México and the Instituto de Investigaciones en Ecosystemas y Sustentabilidad - Universidad Nacional Autónoma de México, Morelia, México. He has an MSc in International Land and Water Management and a $\mathrm{PhD}$ in Social Sciences/Water Governance. His main areas of interest are water governance, community organization, and agrarian change from a political ecology perspective.

\section{ORCID}

Britt Basel (D) http://orcid.org/0000-0002-9507-1383

Jaime Hoogesteger (iD) http://orcid.org/0000-0002-6784-0552

\section{References}

Adger, W.N. (2003). Social capital, collective action, and adaptation to climate change. Economic Geography, 79(4), 387-404. https://doi.org/10. 1111/j.1944-8287.2003.tb00220.x

Bardhan, P. (2000). Irrigation and cooperation: an empirical analysis of 48 irrigation communities in south India. Economic Development and Cultural Change, 48(4), 847-865. https://doi.org/10.1086/452480

Basel, B., Goby, G., \& Johnson, J. (2020). Community-based adaptation to climate change in villages of Western Province, Solomon Islands. Marine Pollution Bulletin, 156, 111266. https://doi.org/10.1016/j. marpolbul.2020.111266

Berkes, F., \& Armitage, D. (2010). Co-management institutions, knowledge, and learning: Adapting to change in the Arctic. Etudes/Inuit/ Studies, 34(1), 109-131. https://doi.org/10.7202/045407ar

Bodin, Ö. (2017). Collaborative environmental governance: Achieving collective action in social-ecological systems. Science, 357(6352), 1-8. https://doi.org/10.1126/science.aan1114

Boelens, R., \& Hoogesteger, J. (2017). Collective action, community and the peasant economy in Andean highland water control. In D. Suhardiman, A. Nicol., \& E. Mapedza, (Eds.), Water governance and collective action (pp. 96-107). Routledge.

Boillat, S., \& Berkes, F. (2013). Perception and interpretation of climate change among Quechua farmers of Bolivia: Indigenous knowledge as a resource for adaptive capacity. Ecology and Society, 18(4), https:// doi.org/10.5751/ES-05894-180421

Carruthers, D.V. (1996). Indigenous ecology and the politics of linkage in Mexican social movements. Third World Quarterly, 17(5), 1007-1028. https://doi.org/10.1080/01436599615236

CDI Flor y Canto A.C. (April 3, 2018). Xnizaa, sembradores de agua. [video]. YouTube. Retrieved May 30, 2020. https://www.youtube. $\mathrm{com} /$ watch? $\mathrm{v}=\mathrm{GvUJwI7HAmc}$

Centro de Derechos Indígenas Flor y Canto. (n.d.). Consulta indígena en los valles centrales. Retrieved May 18, 2020. https://cdiflorycanto.org/ web/consulta-indigena/

CONAGUA. (n.d.). Normales Climatológicas por Estado. Retrieved June 10, 2020, from https://smn.conagua.gob.mx/es/informacionclimatologica-por-estado? estado $=$ oax

Dell'Angelo, J., Rulli, M. C., \& D'Odorico, P. (2018). The global water grabbing syndrome. Ecological Economics, 143, 276-285. https://doi. org/10.1016/j.ecolecon.2017.06.033

Delgado Moya, R. (1999). Constitución Política de los Estado Unidos Mexicanos. Comentada. Editorial Lista.

Di Baldassarre, G., Sivapalan, M., Rusca, M., Cudennec, C., Garcia, M., Kreibich, H., Konar, M., Mondino, E., Mård, J., Pande, S., Sanderson, M.R., Tian, F., Viglione, A., Wei, J., Wei, Y., Yu, D.J., Srinivasan, V., \& Blöschl, G. (2019). Sociohydrology: Scientific challenges in addressing the sustainable development goals. Water Resources Research, 55(8), 6327-6355. https://doi.org/10.1029/2018WR023901

Di Baldassarre, G., Viglione, A., Carr, G., Kuil, L., Salinas, J.L., \& Blöschl, G. (2013). Socio-hydrology: Conceptualising human-flood interactions. Hydrology and Earth System Sciences, 17(8), 3295-3303. https://doi.org/10.5194/hess-17-3295-2013

Diario Oficial de la Federación (DOF). (25 de septiembre de 1967). Decreto que establece veda por tiempo indefinido para el alumbramiento de aguas del subsuelo en la zona conocida como Valle de Oaxaca, cuya extensión y límites geopolíticos comprenden los ex distritos de Etla, Centro, Tlaxolula, Zimatlán y Ocotlán, Oaxaca. Secretaría de Recursos Hidraúlicos (SRH). Recuperado el 29 de 
mayo de 2020 de http://www.dof.gob.mx/index.php?year= $1967 \&$ month $=09 \&$ day $=25$

Dillon, P., Stuyfzand, P., Grischek, T., Lluria, M., Pyne, R.D.G., Jain, R.C., Bear, J., Schwarz, J., Wang, W., Fernandez, E., Stefan, C., Pettenati, M., van der Gun, J., Sprenger, C., Massmann, G., Scanlon, B.R., Xanke, J., Jokela, P., Zheng, Y., ... Sapiano, M. (2019). Sixty years of global progress in managed aquifer recharge. Hydrogeology Journal, 27, 1-30. https://doi.org/10.1007/s10040-018-1841-z

Dodman, D., \& Mitlin, D. (2011). Challenges for community-based adaptation: Discovering the potential for transformation. Journal of International Development, 25(5), 640-659. https://doi.org/10.1002/ jid. 1772

Falkenmark, M., Berntell, A., Jägerskog, A., Lundqvist, J., Matz, M., \& Tropp, H. (2007). On the verge of a new water scarcity: A call for good governance and human ingenuity. In SIWI Policy Brief. Stockholm International Water Institute (SIWI).

FAO. (2000). "Manual de Prácticas integradas de manejo y conservación de suelos" Boletín de tierra y aguas de la FAO.

Few, R., Brown, K., \& Tompkins, E. 2007. Public participation and climate change adaptation: Avoiding the illusion of inclusion. Climate Policy, 7, 46-59. https://doi.org/10.1080/14693062.2007.9685637

Finley-Brook, M., \& Thomas, C. (2010). From malignant neglect to extreme intervention: Treatment of displaced indigenous populations in two large hydro projects in Panama. Water Alternatives, 3(2), 269-290.

Flannery, K.V., Kirkby, A.V.T., Kirkby, M.J., \& Williams, A.W. (1967). Farming systems and political growth in ancient Oaxaca: Physiographic features and water-control techniques contributed to the rise of Zapotec Indian civilization. Science, 158(3800), 445-454. https://doi.org/10.1126/science.158.3800.445

Forsyth, T. (2001). Critical realism and political ecology. In After postmodernism: An introduction to critical realism (pp. 146-154). Athlone Press.

Forsyth, T. (2017). Community-based adaptation to climate change. Oxford Research Encyclopedia of Climate Science, 1. https://doi.org/ 10.1093/acrefore/9780190228620.013.602

Gamboa Montejano, C., \& Valdés Robledo, S. (2018). Cámara de Diputados. No. SAPI-ISS-04-18 LOS USOS Y COSTUMBRES DE PUEBLOS INDIGENAS Derecho Comparado a Nivel Estatal. Dirección General de Servicios de Documentación, Información y Análisis.

Gardner, R., Ostrom, E., \& Walker, J.M. (1990). The nature of commonpool resource problems. Rationality and Society, 2(3), 335-358. https:// doi.org/10.1177/1043463190002003005

Gohari, A., Eslamian, S., Mirchi, A., Abedi-Koupaei, J., Bavani, A.M., \& Madani, K. (2013). Water transfer as a solution to water shortage: A fix that can backfire. Journal of Hydrology, 491, 23-39. https://doi. org/10.1016/j.jhydrol.2013.03.021

Gosling, S. N., \& Arnell, N. W. (2013). A global assessment of the impact of climate change on water scarcity. Climatic Change, 134(3), 371-385. https://doi.org/10.1007/s10584-013-0853-x

Grupo De Estudios Ambientales Y Sociales, Gea A.C. (2011). Diagnóstico del estado de conservación de la biodiversidad de la microrregión Minas-Tilquiapam-Chichicapam-Güilá, Oaxaca, México. Ciudad de México.

Grupo Mesófilo A.C. (2012). "Ordenamiento Territorial Comunitario De Santa Catarina Minas” Programa De Conservación Comunitaria De La Biodiversidad (Coinbio).

Grupo Sturnira Oaxaca S.C. (2011a). "Evaluación Rural Participativa De La Comunidad De San Miguel Tilquiapam" Programa De Conservación Comunitaria De La Biodiversidad (Coinbio).

Grupo Sturnira Oaxaca S.C. (2011b). "Evaluación Rural Participativa Del Ejido De San Dionisio Ocotepec" Programa De Conservación Comunitaria De La Biodiversidad (Coinbio).

Grupo Sturnira Oaxaca S.C. (2011c). “Ordenamiento Territorial Comunitario De San Baltazar Chichicapam" Programa De Conservación Comunitaria De La Biodiversidad (Coinbio).

Grupo Sturnira Oaxaca S.C. (2011d). "Ordenamiento Territorial Comunitario De San Baltazar Chichicapam" Programa De Conservación Comunitaria De La Biodiversidad (Coinbio).
Guyennon, N., Salerno, F., Portoghese, I., \& Romano, E. (2017). Climate change adaptation in a Mediterranean semi-arid catchment: Testing managed aquifer recharge and increased surface reservoir capacity. Water, 9(9), 1-18. https://doi.org/10.3390/w9090689

Hall, R.J. (2015). Divide and conquer: Privatizing indigenous land ownership as capital accumulation. Studies in Political Economy, 96(1), 2346. https://doi.org/10.1080/19187033.2015.11674936

Hardin, G. (1968). The tragedy of the commons. Science, 162(3859), 1243-1248. https://doi.org/10.1126/science.162.3859.1243

Herencia de Restauración Forestal. (2006). "Protección, restauración y conservación de suelos forestales. Manual de obras y practices" SEMARNAT-CONAFOR.

Hicks, G.A., \& Peña, D.G. (2003). Community acequias in Colorado's Rio Culebra watershed: a customary commons in the domain of prior appropriation. Colorado Law Review, 74(2), 101-200.

Hidalgo, J.P., Boelens, R., \& Vos, J. (2017). De-colonizing water. Dispossession, water insecurity, and indigenous claims for resources, authority, and territory. Water History, 9(1), 67-85. https://doi.org/ 10.1007/s12685-016-0186-6

Hoogesteger, J. (2013). Trans-forming social capital around water: Water user organizations, water rights, and nongovernmental organizations in Cangahua, the Ecuadorian Andes. Society and Natural Resources, 26(1), 60-74. https://doi.org/10.1080/08941920.2012.689933

Hoogesteger, J. (2015). Normative structures, collaboration and conflict in irrigation; a case study of the Pillaro north Canal irrigation system, Ecuadorian highlands. International Journal of the Commons, 9(1), 398-415. https://doi.org/10.18352/ijc.521

Hoogesteger, J. (2018). The ostrich politics of groundwater development and neoliberal regulation in Mexico. Water Alternatives, 11(3), 552-571.

Hoogesteger, J., Boelens, R., \& Baud, M. (2016). Territorial pluralism: Water users' multi-scalar struggles against state ordering in Ecuador's highlands. Water International, 41(1), 91-106. https://doi. org/10.1080/02508060.2016.1130910

Hoogesteger, J., \& Rivara, F. (2020). The end of the rural/urban divide? Migration, proletarianization, differentiation and peasant production in an ejido, Central Mexico. Journal of Agrarian Change, online first. https://doi.org/10.1111/joac.12399

Hoogesteger, J., Tiaguaro-Rea, Y., Rap, E., \& Hidalgo, J.P. (2017). Scalar Politics in Sectoral Reforms: Negotiating the implementation of water policies in Ecuador (1990-2008). World Development, 98, 300 309. https://doi.org/10.1016/j.worlddev.2017.04.036

Hoogesteger, J., \& Verzijl, A. (2015). Grassroots scalar politics: Insights from peasant water struggles in the Ecuadorian and Peruvian Andes. Geoforum; Journal of Physical, Human, and Regional Geosciences, 62, 13-23. https://doi.org/10.1016/j.geoforum.2015.03.013

Hoogesteger, J., \& Wester, P. (2017). Regulating groundwater use: The challenges of policy implementation in Guanajuato, central Mexico. Environmental Science \& Policy, 77, 107-113. https://doi.org/10. 1016/j.envsci.2017.08.002

International Groundwater Assessment Centre. (n.d.). Managed Aquifer Recharge (MAR). Retrieved June 09, 2020, from https://www.unigrac.org/areas-expertise/managed-aquifer-recharge-mar

Jiménez Cisneros, B.E., Oki, T., Arnell, N.W., Benito, G., Cogley, J.G., Döll, P., Jiang, T., \& Mwakalila, S.S. (2014). Freshwater resources. In C. B. Field, V. R. Barros, D. J. Dokken, K. J. Mach, M. D. Mastrandrea, T. E. Bilir, M. Chatterjee, K. L. Ebi, Y. O. Estrada, R. C. Genova, B. Girma, E. S. Kissel, A. N. Levy, S. MacCracken, P. R. Mastrandrea, \& L. L. White (Eds.), Climate change 2014: Impacts, adaptation, and vulnerability. Part A: global and sectoral aspects. Contribution of working group II to the fifth Assessment Report of the Intergovernmental Panel on climate change (pp. 229-269). Cambridge University Press.

Kahn, M., Rashid, A., \& Shaw, R. (2013). Community based adaptation: Theory and practice. In R. Shaw, F. Mallick, \& A. Islam (Eds.), Climate change adaptation actions in Bangladesh (pp. 341-362). Springer. https://doi.org/10.1007/978-4-431-54249-0_18

Kallis, G. (2010). Coevolution in water resource development: The vicious cycle of water supply and demand in Athens, Greece. Ecological Economics, 69(4), 796-809. https://doi.org/10.1016/j.ecolecon.2008. 07.025 
Karim, M.R., \& Thiel, A. (2017). Role of community based local institution for climate change adaptation in the Teesta riverine area of Bangladesh. Climate Risk Management, 17, 92-103. https://doi.org/ 10.1016/j.crm.2017.06.002

Kennedy, D. (1995). Water supply and use in the southern Hauran, Jordan. Journal of Field Archaeology, 22(3), 275-290. https://doi.org/ $10.2307 / 530176$

Kummu, M., Guillaume, J. H. A., de Moel, H., Eisner, S., Flörke, M., Porkka, M., Siebert, S., Veldkamp, T. I. E., \& Ward, P. J. (2016). The world's road to water scarcity: Shortage and stress in the 20th century and pathways towards sustainability. Scientific Reports, 6(1). https:// doi.org/10.1038/srep38495

Lasage, R., Muis, S., Sardella, C.S.E., Van Drunen, M.A., Verburg, P.H., \& Aerts, J.C.J.H. (2015). A stepwise, participatory approach to design and implement community based adaptation to drought in the Peruvian Andes. Sustainability, 7(2), 1742-1773. https://doi.org/10.3390/su7021742

Ley de Aguas Nacionales (LAN). (1992). Ley de Aguas Nacionales y su Reglamento. Last reform to the law published 24/03/2016. Government of the Republic of Mexico

Lasage, R., \& Verburg, P.H. (2015). Evaluation of small-scale water harvesting techniques for semi-arid environments. Journal of Arid Environments, 118, 48-57. https://doi.org/10.1016/j.jaridenv.2015.02.019

Levin, S. A. (1992). The problem of pattern and scale in ecology. In T. M. Powell, \& J. H. Steele, (Eds.), Ecological time series. Springer, Boston, MA. https://doi.org/10.1007/978-1-4615-1769-6_15

Loucks, D.P. (2015). Debates-perspectives on socio-hydrology: Simulating hydrologic-human interactions. Water Resources Research, 51(6), 4789-4794. https://doi.org/10.1002/2015WR017002

Malik, R., Giordano, M., \& Sharma, V. (2014). Examining farm-level perceptions, costs, and benefits of small water harvesting structures in Dewas, Madhya Pradesh. Agricultural Water Management, 131, 204211. https://doi.org/10.1016/j.agwat.2013.07.002

Martin, G.J., Camacho Benavides, C.I., Del Campo García, C.A., Anta Fonseca, S., Chapela Mendoza, F., \& González Ortíz, M.A. (2011). Indigenous and community conserved areas in Oaxaca, Mexico. Management of Environmental Quality: An International Journal, 22 (2), 250-266. https://doi.org/10.1108/14777831111113419

Martínez Coria, R., \& Haro Encinas, J. A. (2015). Derechos territoriales y pueblos indígenas en México: Una lucha por la soberanía y la nación. Revista Pueblos Y Fronteras Digital, 10(19), 228-256. https://doi.org/ 10.22201/cimsur.18704115e.2015.19.52

Mehta, L., Veldwisch, G. J., \& Franco, J. (2012). Introduction to the special issue: Water grabbing? Focus on the (re)appropriation of finite water resources. Water Alternatives, 5(2), 193-207. https://doi.org/10.1080/ 01436597.2013.843852

Meinzen-Dick, R., Raju, K., \& Gulati, A. (2002). What affects organization and collective action for managing resources? Evidence from Canal irrigation systems in India. World Development, 30(4), 649-666. https://doi.org/10.1016/S0305-750X(01)00130-9

Morçöl, G. (2014). Self-organization in collective action: Elinor Ostrom's contributions and complexity theory. Complexity, Governance \& Networks, (2), 9-22. https://doi.org/10.7564/14-cgn14

Ochoa-Tocachi, B.F., Bardales, J.D., Antiporta, J., Pérez, K., Acosta, L., Mao, F., Zulkafli, Z., Gil-Ríos, J., Angulo, O., Grainger, S., Gammie, G., De Bièvre, B., \& Buytaert, W. (2019). Potential contributions of pre-Inca infiltration infrastructure to Andean water security. Nature Sustainability, 2(7), 584-593. https://doi.org/10.1038/s41893-019-0307-1

Ostrom, E. (2000). Reformulating the Commons. Swiss Political Science Review, 6(1), 29-52. https://doi.org/10.1002/j.1662-6370.2000.tb00285.x

Ostrom, E. (2009a). A general framework for analyzing sustainability of social-ecological systems. Science, 325(5939), 419-422. https://doi. org/10.1126/science.1172133

Ostrom, E. (2009b). Beyond markets and states: Polycentric governance of complex economic systems (Nobel Prize lecture). http://www.nobel prize.org/nobel_prizes/economics/laureates/2009/ostromlecture.html

Ostrom, E. (2009c). Collective action theory. Oxford Handbooks, 1, https://doi.org/10.1093/oxfordhb/9780199566020.003.0008

Ostrom, E., Janssen, M.A., \& Anderies, J.M. (2007). Going beyond panaceas. Proceedings of the National Academy of Sciences, 104(39), 1517615178. https://doi.org/10.1073/pnas.0701886104
Pande, S., \& Sivapalan, M. (2017). Progress in sociohydrology: A metaanalysis of challenges and opportunities. Wiley Interdisciplinary Reviews: Water, 4(4), 1-18. https://doi.org/10.1002/wat2.1193

Pandey, D.N., Gupta, A.K., \& Anderson, D.M. (2003). Rainwater harvesting as an adaptation to climate change. Current Science, 85(1), 46-59. https://doi.org/10.1016/j.ecolind.2017.03.047

Patel, N.G., \& Prabhakar, A.M. (2012). Analysis of rain water harvesting system for artificial recharge of groundwater for Gandhinagar District, Gujarat. Paripex - Indian Journal Of Research, 3(7), 215-216. https:// doi.org/10.15373/22501991/July2014/83

Primack, R., Rozzi, R., Feinsinger, P., Dirzo, R., \& Massardo, F. (2001). Fundamentos de la conservación biológica: Perspectivas latinoamericanas. Fondo de Cultura Económica.

Reid, H. (2016). Ecosystem- and community-based adaptation: Learning from community-based natural resource management. Climate and Development, 8(1), 4-9. https://doi.org/10.1080/17565529.2015. 1034233

Reid, H., Alam, M., Berger, R., Cannon, T., Huq, S., \& Milligan, A. (2009). Community-based adaptation to climate change: An overview. Participatory Learning and Action, 60, 11-33.

Renganayaki, S.P., \& Elango, L. (2013). A review on managed aquifer recharge by check dams: A case study Near Chennai, India. International Journal of Research in Engineering and Technology, 02 (04), 416-423. https://doi.org/10.15623/ijret.2013.0204002

Rockström, J., Falkenmark, M., Allan, T., Folke, C., Gordon, L., Jägerskog, A., ... Varis, O. (2014). The unfolding water drama in the Anthropocene: Towards a resilience-based perspective on water for global sustainability. Ecohydrology, 7, 1249-1261. https://doi.org/10. 1002/eco.1562

Rodima-Taylor, D. (2012). Social innovation and climate adaptation: Local collective action in diversifying Tanzania. Applied Geography, 33, 128-134. https://doi.org/10.1016/j.apgeog.2011.10.005

Rodríguez-Labajos, B., \& Martínez-Alier, J. (2015). Political ecology of water conflicts. Wiley Interdisciplinary Reviews: Water, 2(5), 537558. https://doi.org/10.1002/wat2.1092

Rowles, L. S., Alcalde, R., Bogolasky, F., Kum, S., Diaz-Arriaga, F. A., Ayres, C., Mikelonis, A. M., Toledo-Flores, L. J., Alonso-Gutiérrez, M. G., Pérez-Flores, M. E., Lawler, D. F., Ward, P. M., Lopez-Cruz, J. Y., \& Saleh, N. B. (2018). Perceived versus actual water quality: Community studies in rural Oaxaca, Mexico. Science of The Total Environment, 622-623, 626-634. https://doi.org/10.1016/j.scitotenv. 2017.11.309

Rusca, M., \& Baldassarre, G.D. (2019). Interdisciplinary critical geographies of water: Capturing the mutual shaping of society and hydrological flows. Water, 11(10), 1973. https://doi.org/10.3390/ w11101973

Sadoff, C.W., Hall, J.W., Grey, D., Aerts, J.C.J.H., Ait-Kadi, M., Brown, C., Cox, A., Dadson, S., Garrick, D., Kelman, J., McCornick, P., Ringler, C., Rosegrant, M., Whittington, D., \& Wiberg, D. (2015). Securing water, Sustaining growth: Report of the GWP/OECD task force on water security and sustainable growth. University of Oxford. 180pp.

Santiago Alonso, C., Herrera Ambrosio, Y., Méndez Mota, C., Barmayer, A., \& Salinas Avilés, B. (2011). Sistematización del Proceso social por la Defensa y el Cuidado del Agua impulsado por las comunidades de Valles Centrales. CDI Flor y Canto. Oaxaca-México https:// cdiflorycanto.org/web/revistas/

Savenije, H.H., Hoekstra, A.Y., \& Zaag, P.V. (2014). Evolving water science in the Anthropocene. Hydrology and Earth System Sciences, 18(1), 319-332. https://doi.org/10.5194/hess-18-319-2014

Servicio Meteorológico Nacional de México. (n.d.). Información Estadística Climatológica. Retrieved May 27, 2020, from https://smn conagua.gob.mx/es/climatologia/informacion-climatologica/ informacion-estadistica-climatologica

Shah, T. (2009). Climate change and groundwater: India's opportunities for mitigation and adaptation. Environmental Research Letters, 4(3), 035005. https://doi.org/10.1088/1748-9326/4/3/035005

Srinivasan, V., Konar, M., \& Sivapalan, M. (2017). A dynamic framework for water security. Water Security, 1, 12-20. https://doi.org/10.1016/j. wasec.2017.03.001 
Steins, N., \& Edwards, V. (1999). Collective action in common-pool resource management : The contribution of a social constructivist perspective to existing theory. Society \& Natural Resources, 12(6), 539557. https://doi.org/10.1080/089419299279434

Trawick, P. (2003). Against the privatization of water: An indigenous model for improving existing laws and successfully Governing the commons. World Development, 31(6), 977-996. https://doi.org/10. 1016/S0305-750X(03)00049-4

Troy, T.J., Pavao-Zuckerman, M., \& Evans, T.P. (2015). Debates-perspectives on socio-hydrology: Socio-hydrologic modeling: Tradeoffs, hypothesis testing, and validation. Water Resources Research, 51(6), 4806-4814. https://doi.org/10.1002/2015WR017046

Unión Buin Dannis. (2011). “Diagnóstico del estado de conservación de la biodiversidad de la microrregión Minas-Tilquiapam-ChichicapamGüilá. San Baltazar Chichicapam, Oaxaca, México". GEA A.C. Programa COINBIO 2010.

United Nations Department For Economic And Social Affairs (Un DESA). (2019). Sustainable Development Goals Report 2019. S.1.: United Nations.

Van Steenbergen, F. (2006). Promoting local management in groundwater. Hydrogeology Journal, 14(3), 380-391. https://doi.org/10.1007/ s10040-005-0015-y
Velasco Herrera, R. (2014). Informe final: BUIN DANNIS como Agencia de Desarrollo Local en comunidades de la cordillera central de Valles Centrales, Oaxaca. Union de Comunidades y Ejidod Buin Dannis de la Cordillera Central, Ocotlán-Tlacoulula, A.C.

Wester, P., Hoogesteger, J., \& Vincent, L. (2009). Local IWRM organizations for groundwater regulation: The experiences of the aquifer management councils (COTAS) in Guanajuato, Mexico. Natural Resources Forum, 33(1), 29-38. https://doi.org/10.1111/j.1477-8947. 2009.01206.x

Wester, P., Sandoval-Minero, R., \& Hoogesteger, J. (2011). Assessment of the development of aquifer management councils (COTAS) for sustainable groundwater management in Guanajuato, Mexico. Hydrogeology Journal, 19(4), 889-899. https://doi.org/10.1007/ s10040-011-0733-2

Zeitoun, M., Lankford, B., Krueger, T., Forsyth, T., Carter, R., Hoekstra, A., \& Taylor, R. (2016). Reductionist and integrative research approaches to complex water security policy challenges. ResearchGate.

Zwarteveen, M.Z., \& Boelens, R. (2014). Defining, researching and struggling for water justice: Some conceptual building blocks for research and action. Water International, 39(2), 143-158. https://doi.org/10. 1080/02508060.2014.891168 